\title{
POLICY RESPONSES TO THE ASIAN CURRENCY CRISIS: CASES OF MALAYSIA AND SOUTH KOREA
}

\author{
Tan Soo Kee
}

\section{Introduction}

For the past thirty years, the world has witnessed an increasing number of financial crises. Many studies suggest that capital mobility has been a major cause of global financial instability, in both developed and developing countries. Many observers find that historically, significant waves of increased capital mobility are often followed by a string of domestic banking crises. Other studies suggests that financial crises have multiplied when capital mobility became intensified since 1970s, all with devastating effects on developing economies. ${ }^{1}$ Before the 1997 Asian economic crisis, the IMF thought that capital controls should be banned and discouraged. ${ }^{2}$ However, since the 2008 global crisis the IMF has changed its tune by admitting that capital control would help to smooth the inflows and outflows of capital.

When Malaysia and South Korea were hit by the Asian currency crisis in 1997, both countries responded in similar ways in confronting the crisis in the first one year but subsequently, Malaysia shifted to drastic capital control with effect from September 1 1998. Under the new policy, Malaysia ringgit was pegged at RM3.8 to one US\$ and foreigners were prohibited from taking portfolio capital out of the country for one year. This drastic move had received harsh criticisms from the international community and western analysts. Nonetheless, the stock market went up in the first week of the new regulations and the Malaysian economy improved rapidly since 1999. By June 1999, the Wall Street Journal editorialised that "there never was any doubt that preventing money from fleeing Malaysia could provide short-lived relief." However, some scholars (e.g Jomo KS and Nouriel Roubini) argued that capital control was only imposed one year after the crisis, not during the crisis, which means Malaysia should have already started to recover. Other crisis-hit countries, like Thailand and South Korea also began to regain growth quickly from 1998 without impositions of capital control. Particularly in South Korea, the economy rebounded from its 1998 collapse faster than expected. The short-term IMF policies had resulted in massive unemployment and significant uprooting of the employment sector at the beginning. However, in the longer term, the banking system and corporate sectors of Korea have been fundamentally strengthened compared to pre-crisis period.

1 Ann Pettifor, 'Capital flows, financial crises \& implications for poor countries', PRIME, 6 July 2011. http://www.primeeconomics.org/?p=593.

2 Kevin P. Gallagher,'Control that Capital', Foreign Policy,

29 March2010, http://www.ase.tufts.edu/gdae/Pubs/rp/GallagherFPCapControl.pdf. 
After more than one decade of recovery, the South Korean economy continues to grow rapidly with its innovation driven industries while Malaysia is still caught in the "middle-income trap". Malaysia is still struggling and trying to shift from manufacturing to innovation driven economy. To examine the effectiveness of policies responses to the 1998 Asian currency crisis, this paper compares the economic performance of Korea and Malaysia from 1997to 2010. In the first section, international financial theories are briefly reviewed, and then followed by discussions of capital control and free capital mobility from 1970sto 1990s. The third section discusses how the Asian currency crisis affects the crisis-hit countries and the forth section examines the policy responses of Malaysia and South Korea and their impacts on the economy in the past one decade.

\section{Theories Review}

\section{Mundell Fleming Model}

When a country is hit by financial crisis, which monetary or fiscal policy is more effective to boost aggregate demand? To answer this, Mundell Fleming Model, which explains the linkages between financial system and macroeconomic factors, provides guidance in policymaking. This model is an economic model first set forth (independently) by Robert Mundell. According to Mundell Flemming's M-F Model, when a country chooses to have a floating exchange rate system, fiscal policy is not effective at all in boosting aggregate demand; monetary policy is effective. On the contrary, when a country chooses to have a fixed exchange rate system, monetary policy is not effective at all but fiscal policy is effective. In brief, policy effect depends on situations and structures of the economy and policy choice is an empirical matter. A fiscal expansion has none or little effect on income when a country chooses to have a flexible exchange rate system. The reason is that the initial effect due to the fiscal expansion is completely offset by the appreciated currency if capital is perfectly mobile. The offsetting effect of currency may be less severe depending on the degree of capital mobility. ${ }^{3}$ Fiscal policy achieves the greatest effect on income when capital is immobile. This is equivalent to a closed economy, implying that its effect is always less than that of a closed economy. ${ }^{4}$ In brief, the Mundell-Fleming model has been used to claim that an economy cannot concurrently maintain a fixed exchange rate, free capital movement, and an independent monetary policy. This principle is frequently called "the Unholy Trinity," or "Impossible Trinity".

\section{Theory of Impossible Trinity}

Theory of Impossible Trinity argues that no government can maintain fixed-exchange rates, free capital mobility, and have an independent monetary policy at the same time; one of the three options must give way. A country could only have a combination of any two of these three conditions. In other words, if a country chooses to fix its exchange rate and have monetary autonomy (control of interest rates), it needs capital controls to block international arbitrage flows that would weaken the exchange and interest rate settings. Otherwise, an arbitrage possibility between domestic and foreign interest rates will arise eventually. If it fixes the exchange rate and allows free capital flows, it will lose control over the interest rate since monetary policy must be directed to maintaining

3 Wang, Peiji, The Economic of Foreign Exchange and Global Finance, Berlin: Springer 2005, pp.103-130.

4 Wang, The Economic of Foreign Exchange and Global Finance, pp.103-130. 
the exchange rate. If it fixes the interest rate and permits free capital flows, it will lose control over the exchange rate, which is determined by capital flows. ${ }^{5}$ Independent monetary policy and unrestricted international capital flows can coexist only if the exchange rate is allowed to fluctuate.

Figure 1 Impossible Trinity

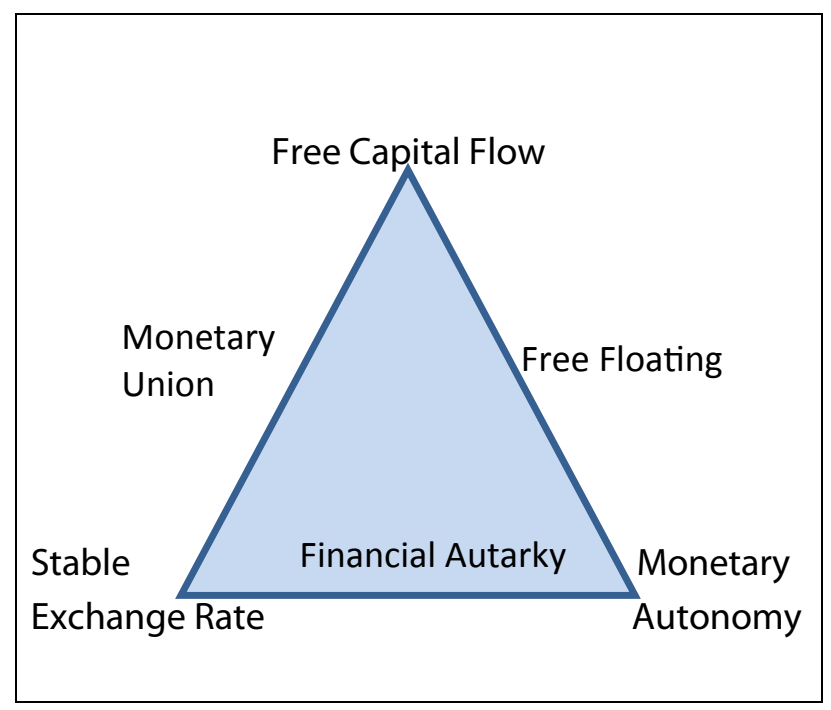

In brief, this theory asserts that a country has to choose between reducing currency volatility and running a stabilising monetary policy; it cannot do both. As stated by Paul Krugman

\begin{abstract}
"The point is that you can't have it all: A country must pick two out of three. It can fix its exchange rate without emasculating its central bank, but only by maintaining controls on capital flows (like China today); it can leave capital movement free but retain monetary autonomy, but only by letting the exchange rate fluctuate (like Britain - or Canada); or it can choose to leave capital free and stabilize the currency, but only by abandoning any ability to adjust interest rates to fight inflation or recession (like Argentina today, or for that matter most of Europe)"
\end{abstract}

When Malaysia and South Korea were hit by the 1997 Asian Financial Crisis, both countries chose orthodox adjustment policy to improve the economy. Both countries tightened the monetary and fiscal policy and allowed free capital flows in the initial stage. However, from September 1 1998, Malaysia made a drastic turn by giving up floating exchange rate. The government imposed extreme capital control, expanded public expenditure and reduced interest rate sharply. In other words, Malaysia chose to have stable exchange rate and monetary autonomy whilst Korea continued to choose free capital flows and monetary autonomy. Experiences of Malaysia and South

5 Thomas I. Palley, 'Rethinking the economics of capital mobility and capital controls', Brazilian Journal of political Economy, Vol. 29, No. 3 115, pp. 15-34, July-September 2009.

6 Paul Krugman. 'O Canada - a neglected nation gets its Nobel', Slate, 10 October 1999. http:// www.slate.com/?id=36764. Retrieved 16 September 2011. 
Korea in dealing with the 1997 Asian Financial crisis provide us the real-life example of experiment in testing which policy is more effective. Because Malaysia chose to restrict capital flows and fixed exchange rate, the Malaysian government adopted fiscal expansion policy. On the other hand, Korea continued to adopt tight fiscal budget, free capital flows and monetary policy to stimulate its economic growth.

\section{Capital Control vs. Free Capital Flow}

Capital controls comprise a set of regulations governing the movement of international capital. Many governments use capital controls regularly to pursue stable exchange rate and export growth. For instance, China has some of the most restrictive control measures and the country is effective in limiting short-term flows while favouring long-term foreign investment. ${ }^{7}$ Even though capital controls are popular among many countries, exchange controls are seen as bad policies among neoclassical economists. From the Neoclassical perspective, capital controls are likened to tariffs levied on goods. These restrictive measures are obviously hurtful to economic efficiency because they inhibit productive resources from being used where they are most needed. ${ }^{8}$ They remove the discipline of the international market, which rewards countries that pursue pro-growth policies and penalises those that do not. ${ }^{9}$ Nevertheless, history shows that many governments have used controls regularly to reduce volatility of capital flows.

During the Bretton-Woods era of fixed-exchange rates, many countries limited asset transactions to cope with balance-of-payments difficulties. ${ }^{10}$ However, from 1970s onwards, developed countries gradually removed strict capital controls in recognition of the costs and distortions of capital controls. One of the examples is the United States, which removed its most prominent capital controls in $1974 .{ }^{11}$ By removing fixed exchange rate systems and liberalising capital flows, countries can avoid large falls in national consumption from economic downturn by selling assets to and/ or borrowing from the rest of the world. Free capital flows policies also permit countries to borrow in order to improve their productivity, very much like individuals borrowing to finance education. ${ }^{12}$ By acknowledging the benefits, more countries began to liberalise capital flows in the early 1990s.

As a result of liberalisation with capital mobility, the search for higher returns from western developed countries led to a surge of foreign capital flows into emerging Asia. In the early 1990s, international commercial and investment banks, securities firms, mutual funds, pension funds, and hedge funds in the U.S, and Western Europe became overflowing with deposits. Consequently, financial capitals were poured into "emerging markets" in search for higher returns. The attractive growth prospects along with higher interest rates and sound domestic macroeconomic policies were forces attracting capital flows into the region. Statistics showed that from the end of 1990 to mid of 1990s, capital flows to developing nations in Asia and Latin America soared from about US\$50billion

7 Carlos F. Liard-Muriente, ' Capital Control: Theory and Practice', Journal of Business and Public Affairs. Vol.1, Issue 1, 2007. http:/ / www.scientificjournals.org/journals2007/articles/1011.htm.

8 Christopher J. Neely, 'An Introduction of Capital Controls', Review, November/December 1999.

9 Carlos F. Liard-Muriente. Capital Control, 2007.

10 Christopher J.Neely, An Introduction of Capital Controls, 1999.

11 Christopher J.Neely, An Introduction of Capital Controls, 1999.

12 Christopher J.Neely, An Introduction of Capital Controls, 1999. 
a year to about US $\$ 300$ billion a year. ${ }^{13}$ Philippines, Thailand, Indonesia and Malaysia were all experiencing money and credit growth rates of between 25to 30 percent a year from 1992to1996. ${ }^{14}$ According to the World Bank report, ${ }^{15}$ East Asia generally absorbed nearly 60 percent of all short-term capital flows to developing countries. Emerging stock markets and property markets boomed. However, the sudden influx of capital flows made the emerging economies more vulnerable to external shocks. During that time, a number of prominent economists and financiers had since pointed out the dangers of volatile capital flows. Joseph Stiglitz, for example, argued that the excessive capital market liberalisation was the significant root cause of the Asian financial crisis. ${ }^{16}$

In mid 1990s, the international capital flows began to return to U.S when domestic interest rate was raised in the U.S. It caused the appreciation of dollar and as a result, spelled financial trouble for the Southeast Asian nations that had currencies pegged to the U.S. dollar. Exports became more expensive and the affected countries became less competitive in the global markets. Export growths began to decline and current accounts deteriorated. For example, Thailand, which had the Thai baht pegged to the U.S dollar, felt the pain and finally abandoned the currency pegging system. When the baht was unexpectedly floated and quickly devalued, it sent a message to foreign investors that there was a substantial exchange rate risk that could not safely be ignored. They responded by rushing to buy foreign currency in order to protect themselves against possible currency devaluation, their fears quickly became a self-fulfilling prophecy. ${ }^{17}$

\section{The Collapse of Asian Currency in 1997}

The collapse of Thai baht triggered the panic selling in the regional currency markets. The crisis began to spread to neighbouring countries, first to Indonesia, then to Malaysia and Korea. As the crisis became full-blown, intense foreign exchange and stock market turmoil spread to the entire region. Among the countries, external value of Indonesian rupiah encountered the worst brunt with 255 percent depreciation on average (see Figure 2) ${ }^{18}$. It plunged from 2500 rupiah in 1997 to more than 10,000 rupiah per USD in 1998. External value of Korean won, ringgit and Thai baht also shrank more than 50 percent on average. For instance, the ringgit fell from an average of 2.42 to the U.S. dollar in April 1997 to an all-time low of 4.88 to the U.S. dollar in January 1998. Until today, after more than ten years of efforts to recover the economy, the Asian currencies have not reached the pre-crisis levels (see Figure 2).

The effects of the crisis lingered through 1998 with political ramifications. In Indonesia, President Suharto was forced to step down on May 211998 in the wake of widespread domestic rioting. The Malaysian Finance Minister Anwar Ibrahim was removed from office and imprisoned. The people of South Korea also voted for political

13 Marshall Auerback, 'A Tale of Two Recoveries-Germany and Malaysia', Part II, News N Economics, 3 March 2010, http:/ / www.newsneconomics.com/2010/03/tale-of-two-recoveries-germany-and.html.

14 Marshall Auerback, 'A Tale of Two Recoveries-Germany and Malaysia', 2010.

15 Quoted in Shalendra D. Sharma, The Asian financial crisis: Crisis, Reform and Recovery, New York: Manchester University Press, 2003, pp.30

16 Marshall Auerback, 'A Tale of Two Recoveries-Germany and Malaysia', 2010.

17 Ross H.McLeod. 'Indonesia'. In Ross H.McLEOD and Ross Garnaut ed., East Asia in Crisis: From Being a Miracle to needing one, London and New York: Routledge, 1998.

18 Depreciation value is calculated based on the difference between the years 1997 and 1998 average value. 
change in the economic aftermath. For the first time in the 50-year existence of the Republic, an opposition party won the presidency in Korea.

Figure 2 Exchange Rates of Asian Currencies per US\$ before and after crisis

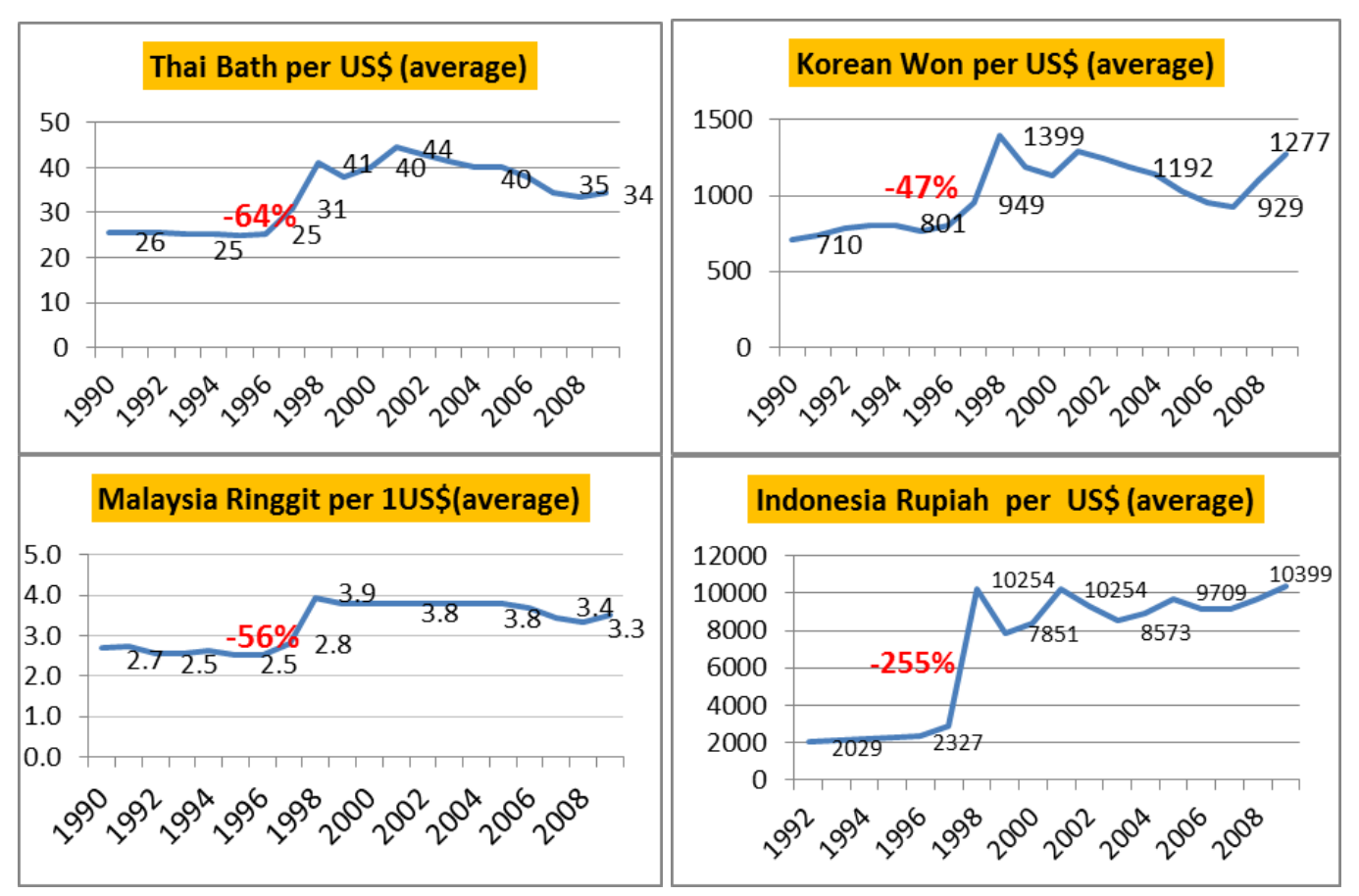

Source: ARIC

The impact of the financial crisis was being felt in the real sector as evidenced by business closures, serious unemployment, and increasing inflation levels. Between July 1997 and April 1998, some 150 Asian financial institutions were shut down, suspended, nationalised, or forced to merge. ${ }^{19}$ Within several months, Thailand, Indonesia and South Korea sought bailout plans from the IMF in the form of financial assistance packages. Malaysia, which had a relatively stronger financial position, did not seek help from the IMF. Prior to the crisis, the Malaysian government had restricted foreign borrowing, which helped to limit the exposure of Malaysian firms and banks to foreign debts, especially the short-term, dollar-denominated obligations. The Malaysian government clearly recognised that the country was not in danger of running out of money; thanks to the lower external debt ratio (see Figure 3) and high international reserve.

As shown by Figure 3 above, the external debt stocks (percentage of GNI) of Malaysia were much lower than Indonesia and Thailand in the pre-crisis period. It was controlled to below 40 percent in Malaysia while those of Indonesia and Thailand exceeded 55 percent from 1995. The ratio skyrocketed to 168 percent for Indonesia in 1998 after sharp depreciation of rupiah. Another crisis-hit country, South Korea that is

19 T.J Pempel, 'The Politics of the Asian Economic Crisis', Ithaca and London: Cornell University Press,1999. 
Figure 3 Externnal Debt Stocks (\% of GNI) of Indonesia Thailand and Malaysia

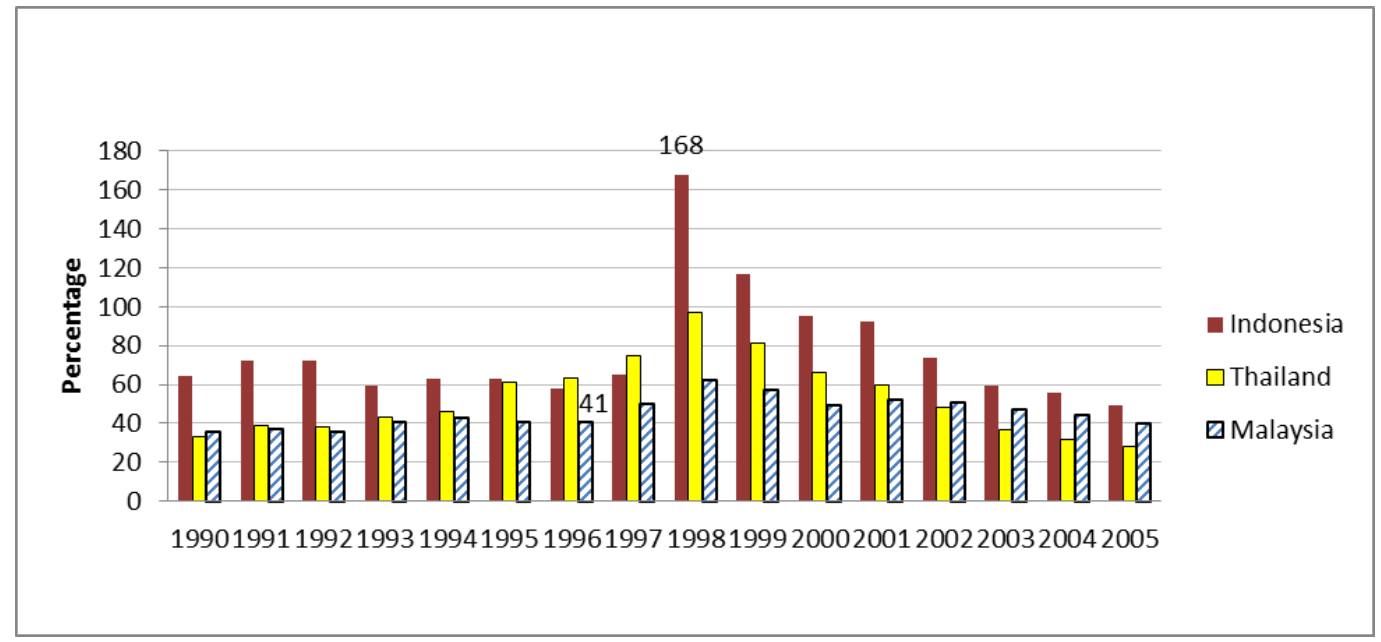

Source: World Development Indicator

not shown in this graph, also had a very high short-term foreign debt ratio prior to 1997. For instance, in 1993 foreign short-term credit in Korea stood at US\$12billion; it rose to $\$ 32$ billion in 1994, $\$ 47$ billion in 1995, and $\$ 67$ billion in 1996. By June 1997, Korea's short-term debt was more than three times the size of its reserves, a ratio higher than that of any other country in the region. ${ }^{20}$ This had generated serious financial stress in the economy of Korea. After the financial crisis, foreign banks demanded immediate repayment of their loans. Pushed to the verge of default, the Thai, Indonesian and Korean governments had no choice but to seek loans from the IMF to repay the foreign debts incurred by their banks and nonfinancial corporations.

\section{Policy Responses and Its Impacts: Case of Malaysia and South Korea}

\section{Tight Monetary and Fiscal Policy in the Initial Stage}

In the initial stage, the Malaysian policy package was copied from the IMF programs although the Malaysian government did not receive the bailout package from the IMF. The IMF, which engineered the solution for the currency crisis in South Korea, Indonesia and Thailand, adopted a "structural adjustment package" which was highly influenced by a neoliberal economic principle. Under the orthodox adjustment policy, practice for a more free market with lesser government intervention is highly advocated. The exchange rate was set to float, interest rate was raised substantially, fiscal policy was tightened, and the banking sector was restructured as well as other structural reforms. The objective of the policy was to regain the stability of the foreign exchange market and to restore the confidence in the country's solvency. By tightening monetary policy with higher interest rate, it aimed to attract capital inflows and to keep inflation low. Malaysia and South Korea both adopted this policy in response to the currency crisis in the initiate stage.

20 Heather Smith, 'Korea'. In Ross H.McLeod and Ross Garnaut ed., East Asia in Crisis from being a miracle to needing one?, London and New York: Routledge, 1998, pp.67. 
To restore the values of currencies, at the end of 1997, interest rates in Malaysia and Korea were raised substantially. In South Korea, interest rate was raised to 30 percent and fiscal policy was sharply tightened in the first half of $1998 .{ }^{21}$ The Malaysian former Finance Minister- Anwar Ibrahim approved the tighter fiscal and monetary policies in December 1997. The central bank of Malaysia, Bank Negara, raised its three-month intervention rate from 8.7 per cent at the end of 1997 to 11.0 per cent in early February 1998. Bank statutory reserve requirements were also raised and tighter definitions of non-performing loans were enforced. ${ }^{22}$ Various plans of infrastructure projects were either cancelled or postponed in Malaysia. A harsh 18 per cent reduction was made in the budgeted government expenditure. ${ }^{23}$ The objective was to address the problem of excessive credit growth as well as the high leverage of some corporations.

Even though the aim of the orthodox adjustment policy was to stabilise exchange rate and inflation, it had worsened the recession even more for both countries in early 1998. In Korea, the combination of financial crisis and austerity macro policy caused a swift drop in economic activity in 1998. Real fixed investments dropped by 22 percent, real consumption by 12 percent, and real GDP by 6.7 percent. ${ }^{24}$ The high interest rate and tight lending policy severely dampened private sector business activity and business community. Sharp rise of interest rate in Korea was hurting the small and mediumsized business sector, with the Bank of Korea reporting 10,000 bankruptcies in the first quarter of 1998, compared with nearly 14,000 for the entire year of $1997 .{ }^{25}$ At the highpoint of the crisis, as many as 100 companies went bankrupt in a day. ${ }^{26}$ In Malaysia, from early 1997 to mid of 1998, capital outflows continued and it was estimated at over $\$ 10$ billion, representing one-third of end-1996 reserves. By mid-1998, the ringgit had depreciated by 40 percent, and the stock market had declined by 75 percent from the pre-crisis levels. ${ }^{27}$ The second quarter GDP contraction of 6.8 per cent plunged Malaysia into recession. Overall, the tight policies resulted in less public expenditures, lower domestic consumption and investment.

\section{Shifting Policy to Expansionary Fiscal and Monetary Policies from 1998}

As the economic situation continued to worsen, policy-makers began to doubt the practicality of the combination of a tight monetary and fiscal policy regime. After several months, the IMF changed its mind and permitted the crisis-hit countries to take more expansionary fiscal and monetary policies. More government intervention was allowed to boost the demand and investment in the Korean economy. Interest rates were sharply reduced to ease the capital cost of the private sectors.

21 James Crotty and Kang-Kook Lee, A Political-Economic Analysis of the Failure of Neoliberal Restructuring in Post-Crisis Korea, 2002. http:/ / people.umass.edu/crotty/CJE-Crotty-Lee-Feb28.pdf.

22 Jomo KS, 'Pathway through Financial Crisis: Malaysia', Global Governance. 2006. http://www. jomoks.org/research/other/rp021.htm

23 Jomo KS, 'Pathway through Financial Crisis: Malaysia', Global Governance. 2006.

24 James Crotty and Kang-Kook Lee, A Political-Economic Analysis of the Failure of Neoliberal Restructuring in Post-Crisis Korea, 2002.

25 Heather Smith, 'Korea'. In Ross H.McLeod and Ross Garnaut 1998. East Asia in Crisis from being a miracle to needing one? London and New York: Routledge. pp.81

26 Hye Jin Zumkehr and Edo Andriesse. Malaysia and South Korea: A Decade after the Asian Financial Crisis. Chulalongkorn Journal of Economics 20(1), April 2008.pp.1-26.

27 Kanita Meesook, 'Comparative Reviews of Policies and Performance', 1997-2000. In Kanita Meesook, II Houng Lee and Olin Liu et.al. ed., Malaysia: From Crisis to Recovery, Washington DC: IMF, 2001. 
In Malaysia, due to deterioration of the economy under the tight budget and monetary policies, in the second quarter of 1998, the Finance Minister Anwar Ibrahim turned away from tight budget to spending policies. However, in the middle of 1998, Anwar Ibrahim was sacked by Mahathir and Daim Zainuddin was appointed the minister in charge of "tasks relating to economic development". Daim and Mahathir shifted the policy by cutting interest rates and expanding credit. As a result, the Base Lending Rate (BLR) for commercial banks fell from 11.96 per cent in March 1998 to 7.24 per cent in July 1999. However, there was little effective change in monetary policies over the ensuing months. The cut of interest rate caused further speculation of ringgit in offshore markets and the ringgit was further depreciated. In order to solve this problem, the Malaysian government imposed extreme capital control from September 1 1998, aiming to cut the link between interest rate and exchange rate.

In Korea, interest rates on three-year bonds were allowed to fall from the peak of $31 \%$ at the end of 1997 to $18 \%$ by April 1998. This was because the extremely high interest rate policy obviously failed to restore the value of won. It had instead caused more bankruptcies of SMEs, more foreign debt, lower investment and consumption. The high interest rate also failed to attract capital inflows due the depreciation risk of Korean won. Alarmed by the sharp deterioration of the economy, the IMF began to soften its stands and permitted Korea to reduce its interest rates. As the won stabilised to the level of 1350-1400 won per dollar by the end of April 1998, it enabled the Korean government to lower interest rate below the 20 percent level, after consultation with

Figure 4 Lending Interest Rate* of Korea and Malaysia

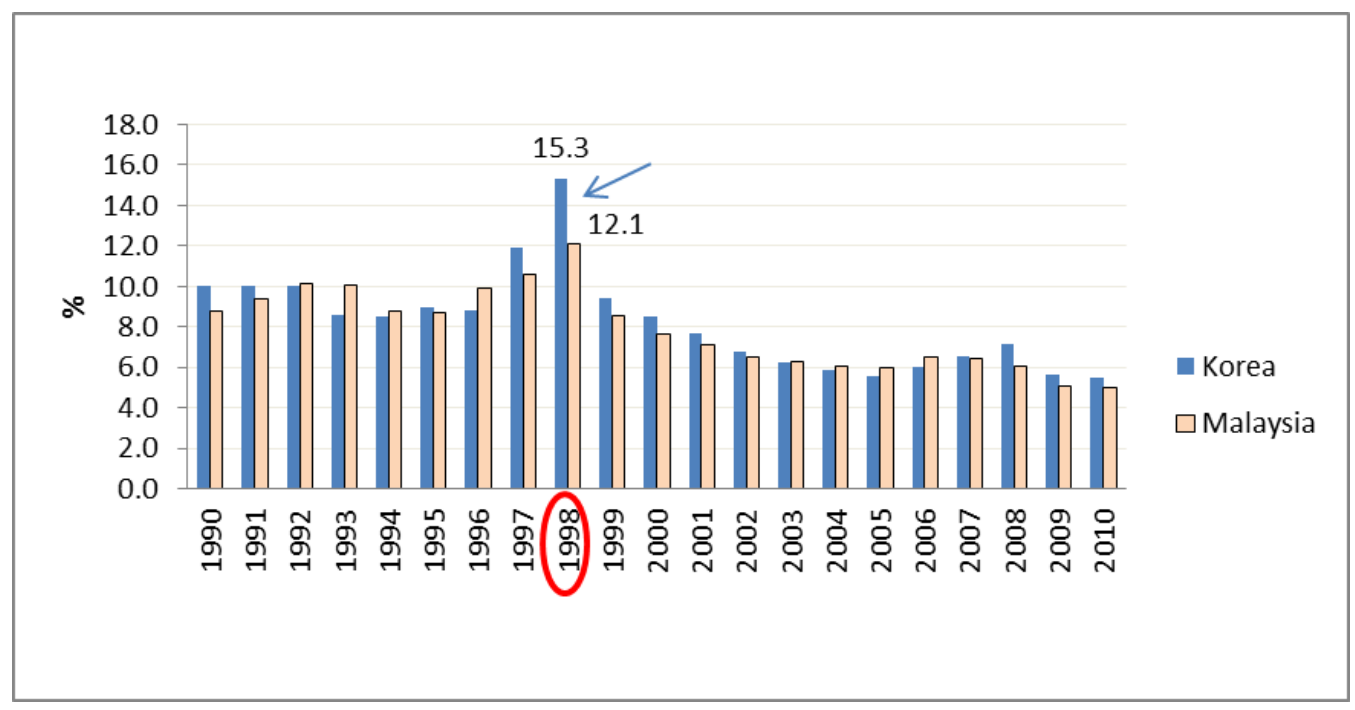

Source: World Bank

* The rate charged by banks on loans to prime customers

the IMF. ${ }^{28}$ Since then, the average interest rate has been gradually reduced as shown by Figure 4.

28 Shalendra D. Sharma. 2003, The Asian Financial crisis: Crisis, Reform and Recovery, UK: Manchester University press, pp. 228. 
As revealed by Figure 4above, the average base lending interest rates of Korea and Malaysia reached its peak in 1998 but they began to decline slowly to a range of 6to 7 percent in recent years. Both countries have adopted loose monetary policies since 1998 in order to ease the burden of business costs in private sectors and to promote investments and consumptions in the economy.

\section{Fiscal Policy from 1998 and its Impact}

Even though the IMF permitted expansionary fiscal policy for Korea from the middle of 1998, the Korean government itself initially insisted on an even tighter fiscal policy, with 1998 budget expenditure rising by only 3.3 percent, the lowest increase in 25 years. In May 1998, the fiscal deficit was raised to 1.2 percent of GDP from 0.8 percent. ${ }^{29}$ Instead of choosing fiscal stimulus, the Korean government continued its prudent fiscal policy by keeping a low fiscal budget. Although public debt as a percentage of GDP roughly doubled since the crisis, it remains at the low end among the OECD countries. Nevertheless, external agencies such as the IMF and the OECD are pushing very hard for a return to fiscal and monetary conservatism. In 2000, the Korean government ran a budget surplus in excess of one percent of GDP, though it shifted to deficit again in early 2001 in response to the slowdown that began in late 2000 (see figure 5). In the first wave of reform, 24,000 positions were phased out by the end of $1998 .{ }^{30} \mathrm{At}$ the end of the year 2000, the number of civil servants had been reduced to 120,000 and the number of cabinet ministries reduced from 21 to $17 .{ }^{31}$ The reduction represented a cut of about 25 percent from the previous year's number. ${ }^{32}$ Besides, privatisations of state-owned enterprises were carried out, which included companies involved in railroads, postal service and telecommunications. These tight measures reflected the governmental commitment to continue the prudent fiscal policy. The continuance of prudent fiscal budget in the past one decade has contributed to the low public debt ratio of Korea.

In Malaysia, fiscal policy was shifted from tightening to expanding mode from 1998, particularly when the government began to impose capital controls from September 1 1998. When Mahathir and Daim took over the Ministry of Finance, interest rates were sharply reduced to encourage banks to lend more. Fiscal budget was enlarged and series of bailouts for troubled firms were approved. To boost the economy following the capital controls, fiscal expansion policy replaced the tight budget policy. To allow higher federal spending, targets of federal government budgets in years 2000 and 2001 were set at achieving deficits of 5.5 percent of GDP and 4.4 percent of GDP respectively. ${ }^{33}$

To bail out troubled firms, the state-owned oil company, PETRONAS, was requested by the Malaysian government to provide financial assistance to particular distressed firms. In the most prominent case, Petronas injected cash into the national car company Perusahaan Otomobil Nasional (known as Proton). A number of companies also received advantageous deals directly from the government. For example, in October 1998 (after 29 Heather Smith, 'Korea', pp.81

30 Roy W. Shin and Yeon Seob Ha, 'Financial Crisis and Policy Reform: The South Korean Experience'. In Liou, Kuotsai Tom eds. Managing Economic Development in Asia : From Economic Miracle to Financial Crisis, 2002. Wesport: Praeger, pp.107

31 Roy W. Shin and Yeon Seob Ha, 'Financial Crisis and Policy Reform: The South Korean Experience', 2002.

32 Roy W. Shin and Yeon Seob Ha, 'Financial Crisis and Policy Reform: The South Korean Experience', 2002.

33 Kanita Meesook, 'Comparative Reviews of Policies and Performance', 1997-2000. 
capital controls were in place), the government paid off some debts of a firm named Renong (a politically well-connected firm and the country's largest conglomerate). In December 2000, the government also extended help to Malaysian Airlines through buying back of the $29 \%$ stake held by Tajudin Ramli in Malaysian Air System (MAS), the operator of Malaysian Airlines. From 2000 to 2001, Malaysia continued to pursue fiscal expansion, whereas other countries had moved to a more neutral stance. In fact, from 1998 until now, the Malaysian federal government continued the budget deficit policy which has driven up the public debt ratio in recent years (see Figure 5).

Figure 5 Fiscal Surplus/Deficit (\% of GDP), Malaysia and Korea

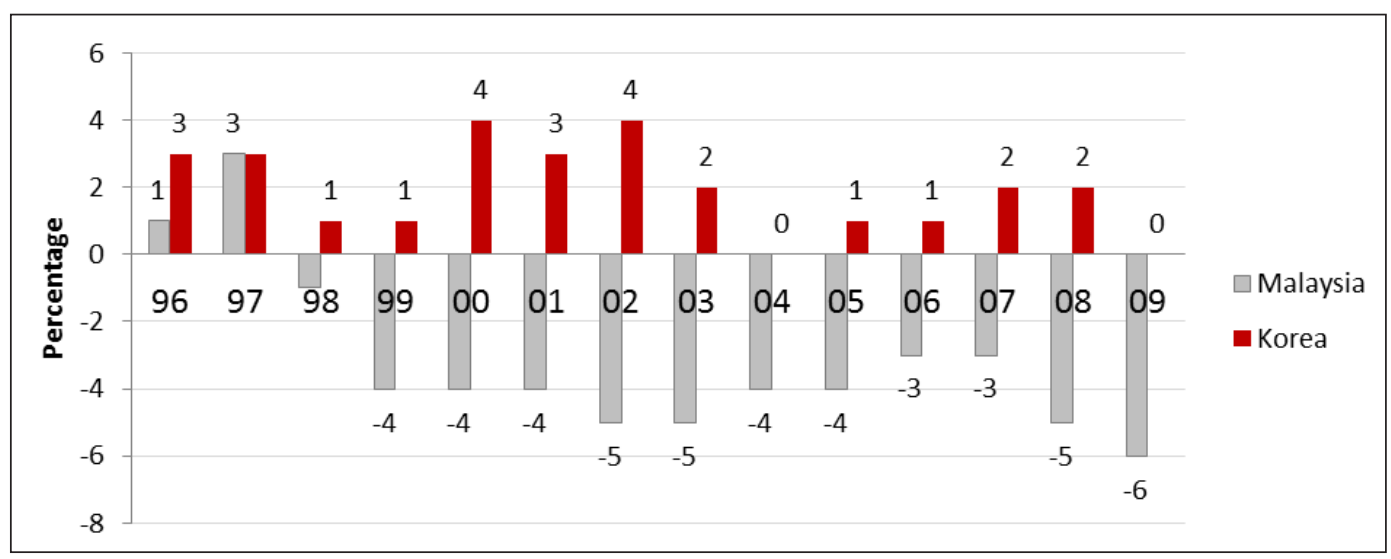

Source: World Economic Idicator

As revealed by Figure 5 above, in the past one decade, the Malaysian government continued to keep the fiscal budgets in deficits while Korean fiscal budgets were kept in surpluses. This explains why the government's gross debt in Malaysia has gone up sharply in recent years. When the global crisis hit Malaysia in 2008, the Malaysian government used the similar approach by expanding government expenditure sharply and this has caused the sharp rise of public debt ratio to GDP to more than 50 percent presently. Although the figure shows that the Korean government's total expenditure as a percentage of GDP also increased, it was tightly controlled and being kept below 20 percent. The Korean government's gross debt as a percentage of GDP also has been kept much lower than that of Malaysia (see Figure 6). In fact, the Malaysian government realised the problem of prolonged fiscal deficits and had tried to shrink the fiscal budget prior to the 2008 global crisis. For example, the fiscal deficit was about 5.5 percent of GDP in 2000 and was reduced to 2.7 percent of GDP in 2007. Nonetheless, when Malaysia was hit by the 2008 global crisis, the figure again climbed very rapidly to 7 percent in 2009 due to the rising of subsidies, public expenditures and economic stimulus package. Despite governmental efforts to reduce subsidies, widen tax base, increase revenues and reduce expenses, the budget deficit hovered around 5 percent in 2010. Gradually, the Malaysian government fell into the pit of fighting high fiscal deficits and public debt problem since the beginning of fiscal expansion policy from 1998. 
Figure 6 Government Total Expenditure

Figure 7 Government Gross Debt

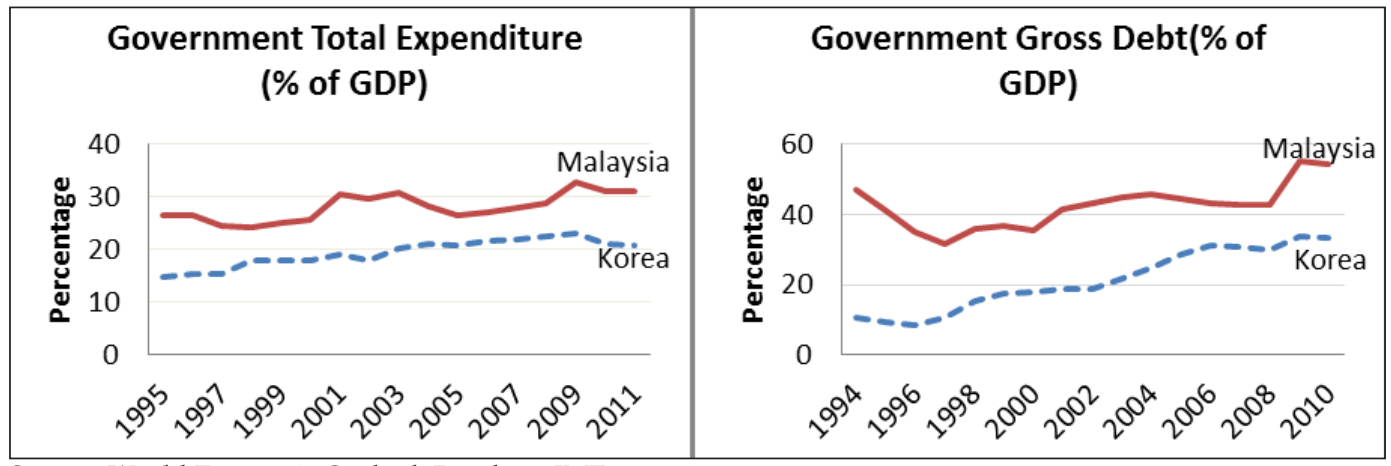

Source: World Economic Outlook Database IMF

The Malaysian government's bailout program of troubled firms received criticisms from several scholars. ${ }^{34}$ Jomo K.S, a prominent economist, commented that "Cronyism awards government contracts to (or bails out) politically connected friends do little to contribute to the country's productive capacity or economic development". ${ }^{35}$ In Jomo's estimation, "the programs were far less successful than the practice of industrial policy in the first-generation NICs of Northeast Asia. In South Korea and Taiwan Province of China, government support for corporate investors was more often tied to performance standards and the potential international competitiveness of their investments". ${ }^{36}$ Based on Figure 6, contribution of government expenditure to the Malaysian economy went up continuously in recent years, but it came with the cost of rising public debt. To prevent Malaysia from facing sovereign debt crisis like what is happening to Greece, undoubtedly the Malaysian government needs to return to firm commitment of prudent fiscal policy.

\section{Malaysia's Capital Control}

Effectiveness of capital control to Malaysian economy remains a hotly debated matter. When Malaysia adopted capital control on September 1 1998, rating agencies such as FITCH IBCA, Moody's, and Standard and Poor's, downgraded Malaysia's sovereign risk rating. However, the Malaysian government, which was under the leadership of Mahathir at that time, chose capital control and pegged the exchange rate in order to stabilise currency exchange market. It then lowered interest rates and increased government spending. The rationale for the drastic move was explained by the Malaysian Prime Minister Dr Mahathir Mohamed as the following:

"We had asked the international agencies to regulate currency trading but they did not care, so we ourselves have to regulate our own currency... But now we can see the damage this system has done throughout the world. It has destroyed the hard work of countries to cater to the interest of speculators as if their interests are so important that millions of people suffer... With the introduction of exchange controls, it would be possible to cut the link between interest rate and the exchange rate... We can reduce interest rates without speculators devaluing our

34 Jomo, K. S. 'Capital controls'. In Jomo K.S ed., Malaysian eclipse: Economic crisis and recovery, London: Zed Books. 2001.

35 Jomo, K. S. Capital controls, 2001

36 Jomo, K. S. Capital controls, 2001. 
currency. Our companies can revive. If our currency is revalued upwards, the companies can buy imports as they don't have to pay so much". ${ }^{37}$

Mahathir questioned the motives of fund managers and "speculators," famously calling George Soros a "moron." To prevent "speculators" from continuing to hurt the Malaysian currency and to cut the link between interest rate and currency, a series of tight capital control measures were imposed as presented below.

\section{Key measures of Malaysia's Capital Control}

- $\quad$ Fixing exchange rate- Peg 1 US\$ to \$3.8 until July 2005

- Elimination of the offshore ringgit market- All ringgit held offshore be repatriated within a month; ringgit held abroad will be invalid. Ringgit lending by Malaysians to foreigners was prohibited.

- Control capital outflows- Foreigners who sold shares on the KLSE could not take the money out of the country for a year. On February 15, 1999, this rule was replaced by graduated taxes on outflows and exit taxes on capital gains ranging from 10 to 30 percent. In September 1999, Bank Negara replaced the two-tier tax with a flat 10 percent exit tax, which it subsequently abolished in February 2001.

- $\quad$ Expand Fiscal Policy by issuing bonds.

- $\quad$ Reduce interest rate from $8.5 \%$ on Sept 1 to $5.5 \%$ on Sept 5 th.

The main reason for the introduction of capital controls in Malaysia was to cut the link between interest rate and exchange rate and to prevent further speculations. However, other countries of the region with IMF's support also began to reduce the interest rates from late 1998 without the needs of controlling capital flows. As shown by Figure 2, Indonesia, Thailand and South Korea's currency exchange rate began to stabilise from 1998 although interest rates were much lower. In Korea, interest rates on three-year bonds were allowed to fall from the peak of 31 percent at the end of 1997 to 18 percent by April 1998. Basically, currencies of all the crisis-hit countries stabilised and strengthened in the same period; their inflation and interest rates fell; current accounts moved from deficit into substantial surplus and private capital inflows increased, contributing to the replenishment of previously depleted foreign exchange reserves.

Following the imposition of capital controls, economic indicators in Malaysia did start to improve. However, other crisis-hit countries which had free capital flows also improved at the same time, particularly South Korea, which was almost insolvent at the end of 1997 (see Figure 8). With domestic demand and the exchange value of won in free fall, the balance of trade improved dramatically in Korea. The real GDP grew by almost 11\% in 1999 and near 9\% in 2000 in Korea. Based on Figure 8, GDP of Korea in 1980 was 64.385 billion dollar and that of Malaysia was 24.94 billion dollar, the gap was 2.58 times. In 2010, GDP of Korea reached 1,014 billion dollar while that of Malaysia was 238 billion dollar; the gap widened to 4.26 times. These numbers suggest that the Malaysian economy trailed even further behind since the Asian crisis (see Figure 8).

37 'Malaysia: Institutes Radical Exchange, Capital Controls', Suns Online, 2 Sept 1998 http:/ / www. sunsonline.org/trade/process/followup/1998/09020098.htm, 
Figure 8 GDP's Comparison (current price) between Korea and Malaysia

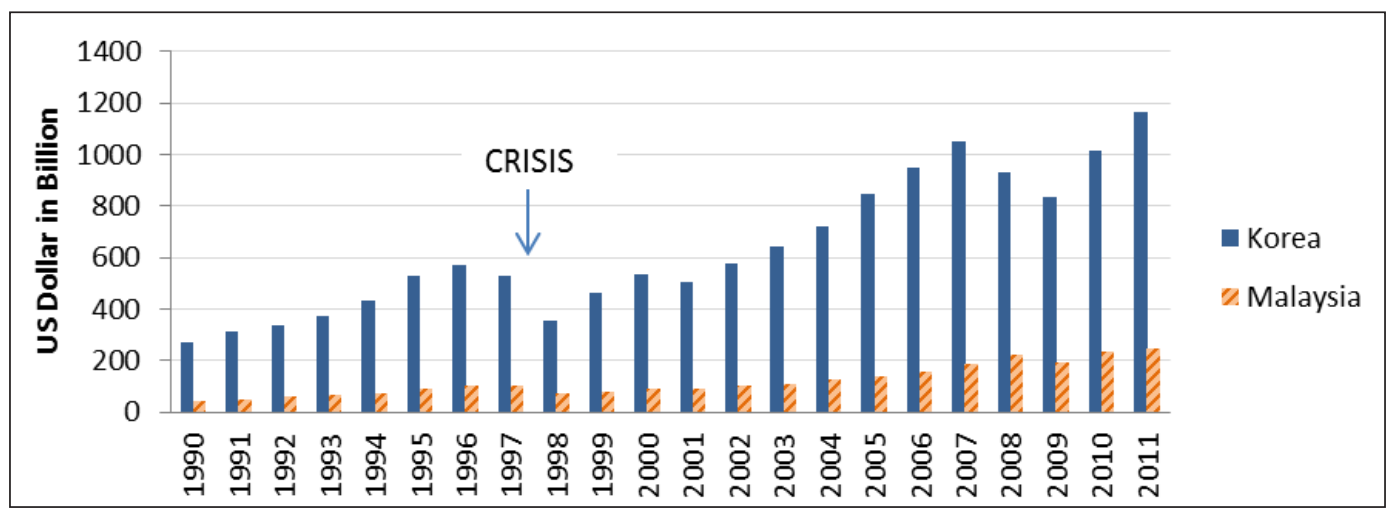

Source: Graph Constructed Based on the Statistics of IMF, World Economic Outlook Database

Given Malaysia's much stronger macroeconomic fundamentals and financial institutions before the crisis, one would have expected its recovery to be faster and stronger than that of the other countries. However, graphic representations of Figure 8 do not suggest that. One of the main reasons was the sharp drop of total investment, particularly the FDI and portfolio investment. Figure 9 reveals that since 1998, the total investment as a percentage of GDP of Malaysia performed poorly compared to that of South Korea, which had free capital flows. Total investment (as a percentage of GDP) in Malaysia fell from 43 percent in 1997 to 22 percent in 1999 and Malaysia has not been able to raise it substantially as shown by Figure 9.

Figure 9 total Investment (\% of GDP), Korea and Malaysia

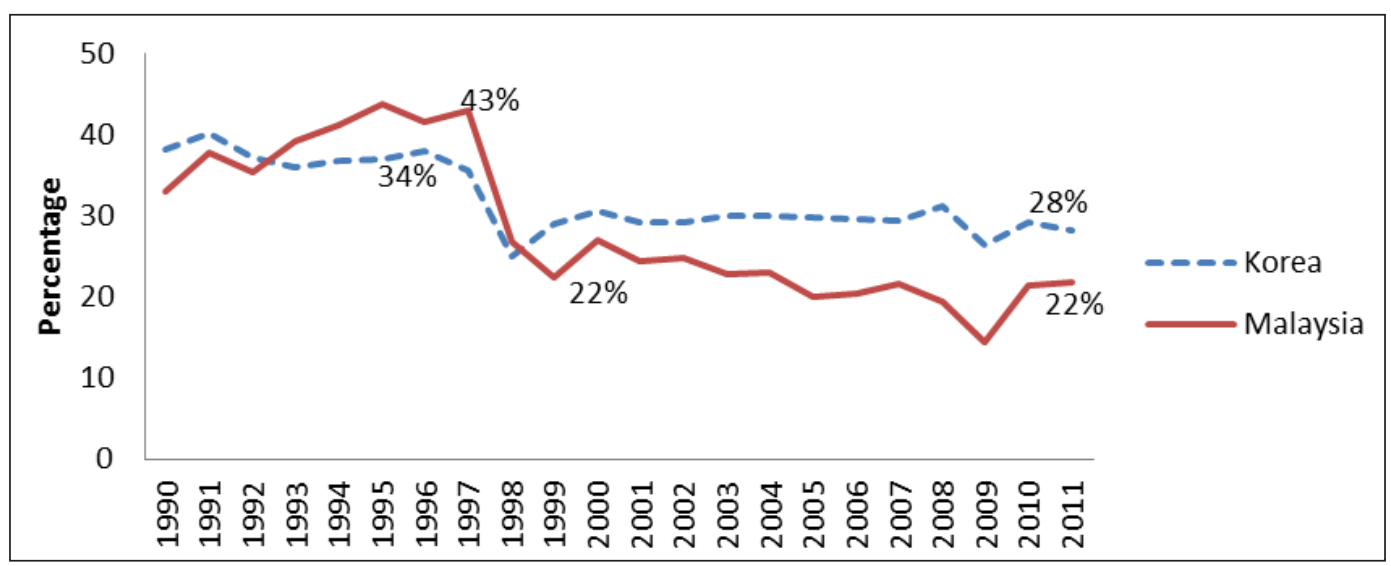

Source: IMF, World Economic Outlook

In fact, the Malaysian government was indeed concerned about the impact of the controls on FDI when the decision was made in 1998. Thus, repatriations of profits and dividends from (documented) FDI activities were freely allowed. Nonetheless, during the period of tight capital controls (1998-2005), FDI inflows to Malaysia performed badly compared to other periods (see Figure 10). 
Figure 10 FDI to Malaysia

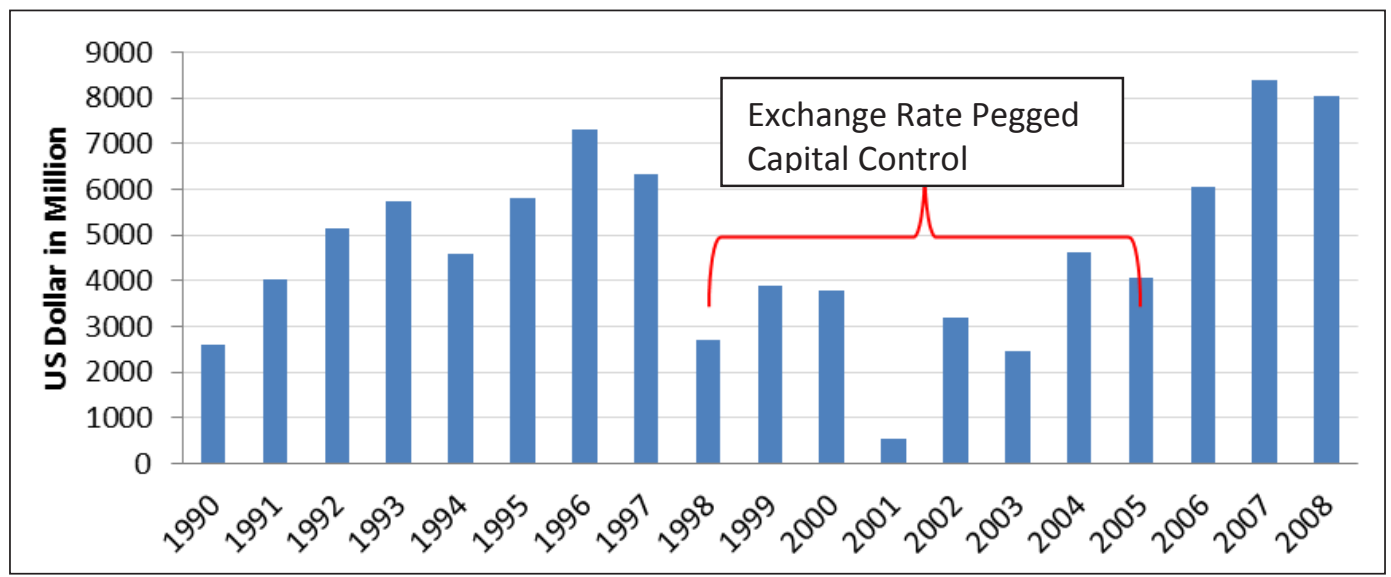

Source: UNCTAD

The financial account, which composed of portfolio investment and FDI has been showing negative flow in Malaysia since 1998 as revealed by Figure 11. The tight capital controls on portfolio investment flows had discouraged foreign investments in the local stock market. South Korea, which has been keeping open capital account, remains as one of the most attractive portfolio investment destinations. As revealed by Figure 12, Korea's financial account (as a percentage of GDP) has been positive from 1999to 2010 except in 2008. However, by keeping free capital flows, the Korean currency exchange rate also experienced more volatility, which created more transaction costs for the import-export businesses.

Figure 11 Financial Account (\% of GDP), Malaysia

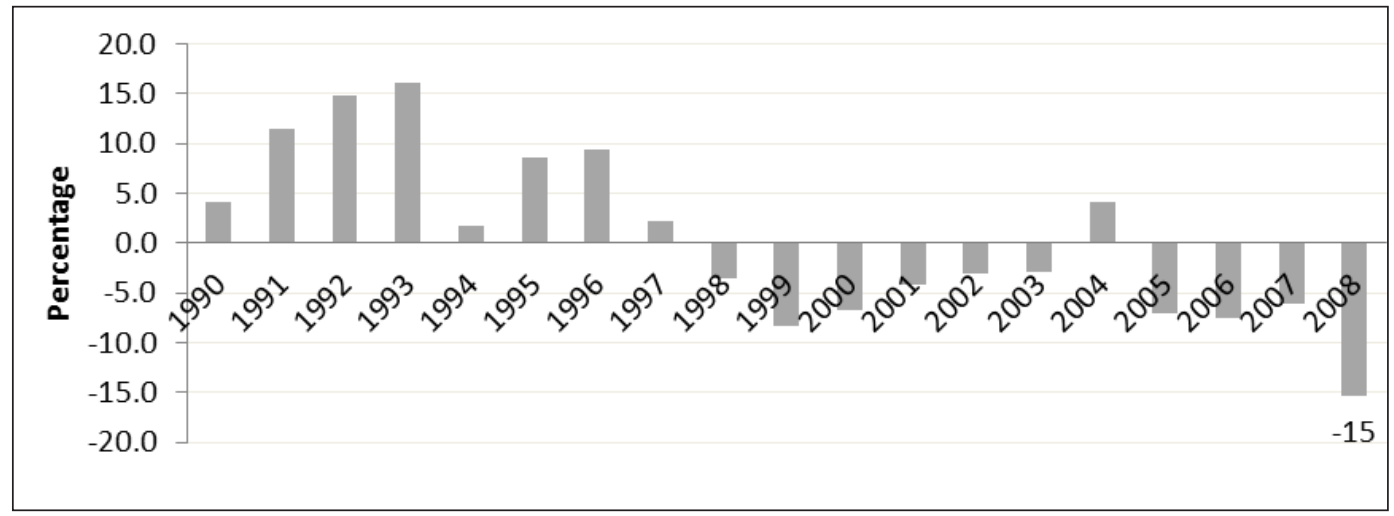

Source: ARIC, ADB

Even though the Mahathir administration and some other studies claimed that the capital control was a successful move, many other scholars disputed the view that the Malaysian capital controls were effective. Studies show that capital controls to the 
Figure 12 Financial Account (\% of GDP)

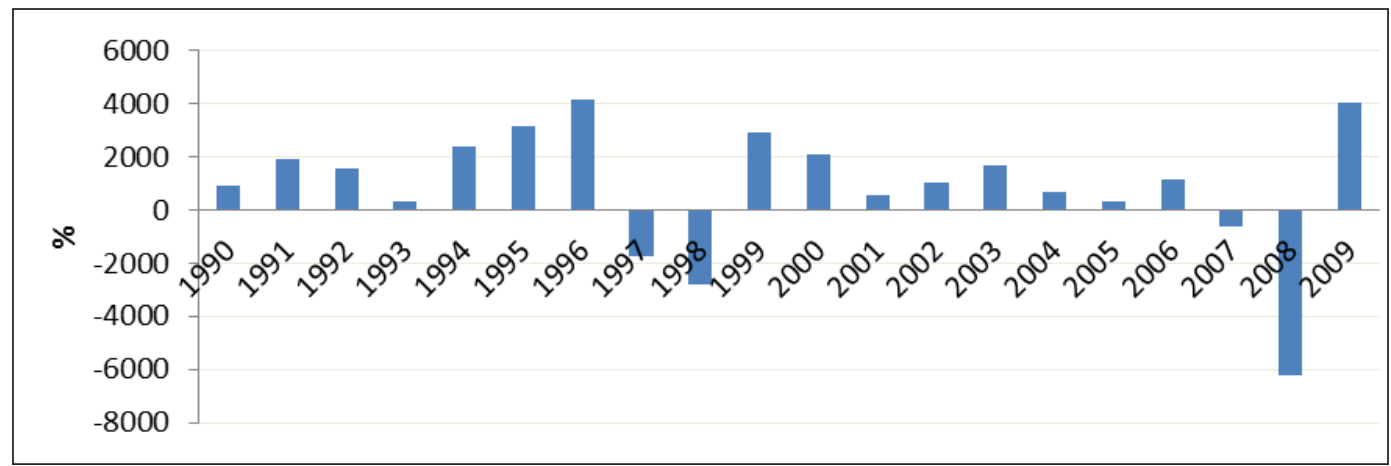

Source: ARIC, ADB

outflows can be a desirable policy tool to combat severe external pressures against the exchange rate. ${ }^{38}$ However, other economists like Jomo KS stated that the contribution of capital controls to Malaysia's recovery was "ambiguous" and it could not be claimed as a success. Nouriel Roubini also argued that, "All the evidence suggests that there is no difference effectively across crisis countries and no evidence to support the claim of the effectiveness of capital control policies in Malaysia". ${ }^{39}$ Paul Krugman suggested that: "Malaysia has proved a point--that controlling capital in a crisis is at least feasible, but cannot be claimed successful. Capital controls had not succeeded in demonstrating that they were the key to recovery" 40 . Capital controls tend to restrict investment growth and to increase economic cost as shown by the case of Malaysia. However, it is undeniable that it has reduced the overall financial fragility, currency risk, and speculative pressures in the economy.

As shown by the case of Korea, the currency and local share market tend to experience more volatility and financial risk under the free capital flow system. During the 2008 global crisis, $\$ 65$ billion was removed from Korea in the four to five months after the 2008 collapse of Lehman Brothers Holdings Inc. ${ }^{41}$ Due to the sudden capital outflows, exchange rate of Korean won to US\$ slumped to 1440 won on Oct 202008 from 1,120 won on September 1 2008. The bumpy ride continued into early 2009 when Korean won hit 1,570 on March 2 2009. To avoid further depreciation of Korean won, the central bank of Korea used the foreign reserves to support Korean won. As a result, the bank's foreign reserves fell sharply, low enough to stir worries about the country's ability to cover its short-term borrowings at a time when investors around the world had become extremely averse to any institution or country with a debt problem. ${ }^{42}$ Overall, the won's volatility has been a major concern to the central bank and government.

38 Ethan Kaplan and Dani Rodrik, Did the Malaysian Capital Controls Work?, 2002.

39 Ethan Kaplan and Dani Rodrik. Did the Malaysian Capital Controls Work? 2002.

40 Paul Krugman, 'Asian Crisis: Capital Control are Feasible', Asia Times, 31 August 1999. http:/ / www.atimes.com/asia-crisis/AH31Db03.html.

41 'South Korea Plans Steps to Reduce Capital-Flow Volatility Soon,' Yim Says,' Bloomberg, 9 June 2010. http:/ / www.bloomberg.com/news/2010-06-09/ south-korea-s-yim-says-economy-not-stableenough-to-justify-higher-rates.html

42 'The Wild Won', The Wall Street Journal, 8 November 2010. http://online.wsj.com/article/SB10 001424052748703843804575533950046046006.html. 
Figure 13below shows the moving trend of Korean won's exchange rate to US\$ from 1981to 2010.

Figure 13 The Wild Korean Won

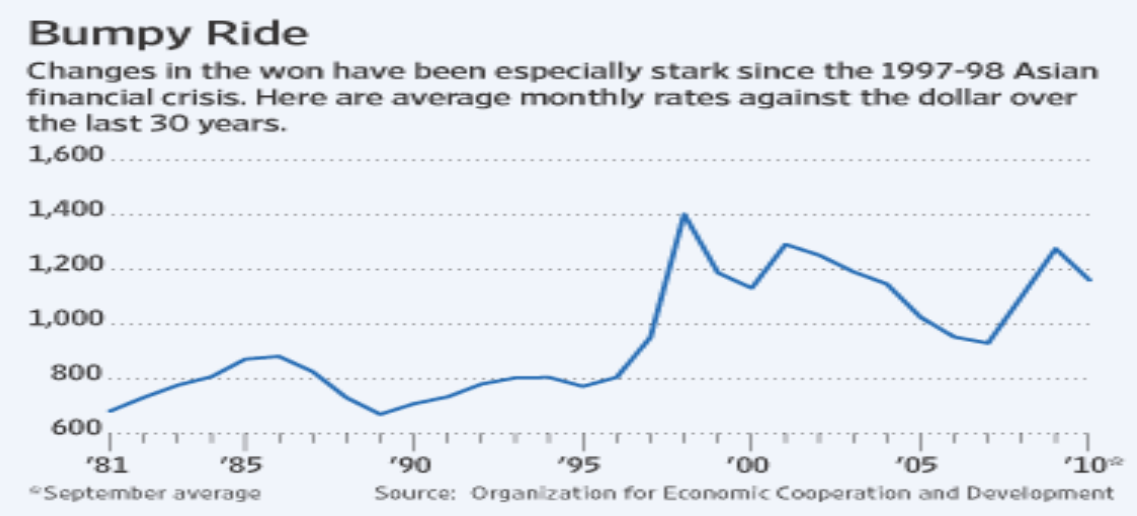

Source: Quoted in Wall Street Journal, 8 November, 2010

\section{Conclusion}

In response to the currency crisis in 1997, Malaysia and Korea both had chosen a different recovery path. While Malaysia opted to have stability of exchange rate and autonomy in fixing interest rate, Korea decided to have free capital flows and flexible monetary policy. Both policies come with advantages and disadvantages. Both economies began to recover quickly from 1999 due to the growth of exports following the sharp depreciations of local currencies. However, the investment climate in Malaysia has not improved much since 1998 to 2009 . As shown by the statistics, the total investments (both FDI and portfolio investment) were in no way impressive during the period of tight capital controls. Instead, the public debt ratio has been growing continuously due to the fiscal expansion policy initiated in 1998. Statistics show that the Malaysian economy is moving towards dependence on the public expenditures. Malaysia cannot expand fiscal deficits forever with the climbing of public debt ratio. The current Greece sovereign debt crisis is a signal to us that protracted fiscal expansions are extremely dangerous and unsustainable. Despite governmental efforts to reduce public expenditures and widen tax base, the Malaysian budget deficit was about 5\% in 2010 and it is expected the public debt's ratio will continue to rise for the coming years. If the rising trend of deficits is not checked, it could add more pressure on the economy and compel the government to think of ways to reduce the debt level. Overall, the temporary drastic capital controls and fiscal expansion policy in Malaysia have adverse effects on the investment climate and escalated the public debt.

Compared to South Korea that has open capital account and tight fiscal budgets, investments and exports rebounded quickly and private sectors have been performing exceedingly well. Nonetheless, the free float exchange rate system in Korea comes with costs too. Currently South Korea is highly vulnerable to short-term capital swings, as 
was witnessed in the 2008to 2009 global crises. The instability of Korean won can be a big concern for a nation where more than 40 percent of economic output comes from the exports. ${ }^{43}$ To reduce the financial fragility and volatile capital flows, the South Korean government has tried to tighten the rules on currency derivatives in recent years. For instance, foreign and domestic banks face lower limits on their holdings of foreignexchange derivatives with effect from 2010. It is an important move to curb swings in the currency trading since the Korean economy is highly dependent on international trades.

Back to the theory of Impossible Trinity, no government can maintain fixedexchange rates, free capital mobility and have an independent monetary policy at the same time; one of the three options must be forgone. Malaysia chose to impose drastic capital controls in response to the currency crisis while Korea gave up fixed-exchanged rate system. Both choices have their advantages and disadvantages depending on economic structure and financial system maturity. To conclude, Malaysia has proved a point that restricting capital flows in a crisis is at least achievable, but with the cost of investment reduction. Korea has enjoyed high growth of investments and exports but faces problems of volatile won. The act of balancing the costs and benefits between free capital flows and capital controls is indeed a challenging art. Questions of how much and how long the controls should be in place remain fundamental issues that require further research.

43 The Wild Won, 8 November 2010. http://online.wsj.com/article/SB10001424052748703843804575533355 0046046006.html 